\title{
Policy Agenda for Sustainable Intermodal Transport in China: An Application of the Multiple Streams Framework
}

\author{
Jiawei Ge ${ }^{1,2}$, Wenming Shi ${ }^{2, *(\mathbb{D})}$ and Xuefeng Wang ${ }^{3}$ \\ 1 Institute of Logistics Science \& Engineering, Shanghai Maritime University, Shanghai 201306, China; \\ gejiawei@stu.shmtu.edu.cn \\ 2 Australian Maritime College, University of Tasmania, Launceston, TAS 7250, Australia \\ 3 College of Transport and Communications, Shanghai Maritime University, Shanghai 201306, China; \\ wangxf@shmtu.edu.cn \\ * Correspondence: wenming.shi@utas.edu.au
}

Received: 25 March 2020; Accepted: 8 May 2020; Published: 11 May 2020

\begin{abstract}
Intermodal transport is widely believed to be an efficient way of organizing transportation activities because of its significant role in reducing logistics costs and emissions of air pollutants, which copes with the ever-increasing economic and environmental concerns. This paper applies the multiple streams framework (MSF) to analyze three streams (e.g., the problem stream, policy stream, and politics stream) in setting policy agenda for sustainable intermodal transport in China. By restricting the attention to the opening of the policy window and the coupling of the three streams, the motivation, process, and trend of formulating intermodal transport policy are systematically discussed. The findings show that the key to setting the policy agenda for sustainable intermodal transport in China is to strengthen collaboration among multiple interest groups, boost the national mood, and diversify the identity of policy entrepreneurs. This paper not only verifies the applicability of the MSF, but also helps us to better understand how sustainable intermodal transport policy is formulated in China, thus promoting future policy making.
\end{abstract}

Keywords: sustainable intermodal transport in China; policy agenda; multiple streams framework; economic and environmental concerns

\section{Introduction}

Intermodal transport is a transport activity that provides door-to-door service by using two or more transport modes, which can effectively reduce logistics costs, increase transport efficiency, and can then contribute to energy savings and air pollutant reduction [1-3]. During the past decades, countries around the world have been making attempts to achieve those benefits through the development of intermodal transport. China, as a latecomer, comes to realize its potential in dealing with such economic and environmental concerns that urge it to build a sustainable intermodal transport system.

China's logistics costs remain high in the national economy. Compared with most developed countries, the proportion of logistics costs in China's Gross Domestic Production (GDP) is double, whereby transportation and inventory costs account for $85 \%$ [4]. Due to the government's efforts on price regulation, the proportion was reduced from 18\% in 2012 to $14.6 \%$ in 2017, however, it is still above the global average (12\%) [5]. As a substitute for price incentive policies, intermodal transportation has great potential for logistics costs reduction. The seamless transport, thanks to intermodalism, effectively relieves the pressure from transportation and inventory costs, as well as improving transport efficiency.

Like the United States (US) and some European countries, intermodal transport in China also refers to the modal shift from road dominance to rail and water, which reduces roadside emissions by 
achieving economies of scale [6]. According to the National Bureau of Statistics (www.stats.gov.cn/tisj/), over $70 \%$ of goods were transported via trucks in China, which has higher unit emissions than other modes of transport. Although the Chinese government has appealed to reduce road transportation, an interesting phenomenon has occurred in the transport market, in that the road freight volume kept increasing with a more competitive price. Meanwhile, the road freight section accounted for $57.3 \%$ and $77.8 \%$ of the total road emission of nitrogen oxide and particulate matter, respectively [7]. Therefore, it is urgent to reduce the heavy reliance on road transport to control air pollution in China, which can be achieved by promoting intermodal transport.

Due to the benefits in cost-saving and environmental protection, China has started to develop its intermodal transport system through collaboration among ports, shipping companies, and land transport operators since the early 1980s. After three years of trial operations at the ports of Shanghai, Tianjin, and Dalian, a standard mode of intermodal transport was officially introduced to other regions in 1993. However, the government did not take further action to promote intermodal transport, leading to sluggish growth of intermodal transport volume in China. Although China's freight trade volume experienced a rapid increase in recent years, intermodal transport only accounted for $2.9 \%$ of the total freight volume in 2017, which was found to be over 20\% in Europe [8] and nearly $40 \%$ in the US [9].

Since the current practice of intermodal transport in China is policy-driven, a sustainable intermodal transport policy is required to create a sustainable environment, which is of crucial importance in fostering the basis of an intermodal transport system. Moreover, the insufficient development of intermodal transport in China is commonly due to the lack of systematic regulation of intermodalism [10]. For example, the Ministry of Transport launched several intermodal projects such as "Pilot Lines for Sea-Rail Intermodal Transport (PIT)" in 2011. Unfortunately, due to technical, institutional, and managerial constraints, none of the pilot lines reached their targets, except for the ports of Shenzhen, Qingdao, and Ningbo. The lack of systemic and sustainable policy design for developing intermodal transport in China resulted in inefficient collaboration and coordination among different parties in the intermodal transport system. This severely hindered the progress of government-controlled transport projects. Therefore, the potential for logistics cost reduction from intermodal transportation cannot be inspired.

To overcome the above policy limitation, 18 government departments, including the Ministry of Transport, jointly issued the "Notification on Further Encouraging Intermodal Transport" (hereinafter referred to as the "Notification") in January 2017, aiming to create a sustainable environment for developing intermodal transport through institutional design, technological breakthrough, and international cooperation. The Notification has laid the foundation and pointed out the direction of China's sustainable intermodal transport policy, after which intermodal transport volume in 2020 is expected to be 1.5 times higher than that in 2015 , achieving more than $20 \%$ of the compound annual growth rate [11].

Therefore, this paper aims to test the applicability of the multiple streams framework (MSF) by analyzing three streams (e.g., the problem stream, policy stream, and politics stream) in setting policy agenda for sustainable intermodal transport in China. Meanwhile, this paper aims to identify key factors in setting China's intermodal transport policy. By achieving the two objectives, this paper makes contributions in the following two aspects. First, an in-depth analysis of the problem stream, policy stream, and politics stream in setting intermodal transport policy in China verifies the applicability of the MSF, providing a comprehensive framework for us to better understand the policy-making process. Second, a systematic discussion of the motivation, process, and trend of China's intermodal transport policy identifies that the key for policy making is to strengthen collaboration among multiple interest groups, boost the national mood, and diversify the identity of policy entrepreneurs.

The remainder of this paper is structured as follows. Section 2 discusses the theoretical framework of MSF in the context of China. Section 3 analyzes the problem stream, policy stream, and politics stream in formulating China's intermodal transport policy. Section 4 presents the coupling analysis 
of the three streams, further explaining the policy-making process for intermodal transport in China. Section 5 concludes this paper.

\section{Theoretical Framework}

Derived from the garbage can model [12], the MSF was proposed by American policy scientist Kingdon, and its theoretical framework consists of three parallel and independent parts which are the problem stream, policy stream, and politics stream. At a specific time, the three streams are coupled to each other because of external actions, the so-called "policy window", and finally come to the official policy agenda.

Since then, the MSF has been adapted worldwide in explaining public policy agenda setting, providing a reference for identifying factors in policy making and implementation in a complex environment [13]. More specifically, the problem stream originates from various social situations, which are affected by people's perceptions (e.g., value, attitude, experience, understanding, etc.), and draws policy makers' attention by using indicators, focusing events and feedback. An actual social situation is then transformed into a public problem and urges policy makers to take actions to resolve it. The policy stream is similar to the process of biological natural selection, where a policy community is composed of scholars, practitioners, and government officials who propose possible solutions or ideas to form a "primeval policy soup" and assess the applicability through certain criteria (e.g., technical feasibility, economic viability and operability). Better alternatives are obtained through constant comparison or integration. In Kingdon's model, the politics stream consists of national mood, pressure group campaigns, and partisan or ideological distribution in Congress, etc. As the three streams flow in the policy-making system, the policy entrepreneurs come to the stage with recognized problems and developed proposals. The three separate streams then couple together when a political change happens, namely the openness of policy window. The occurrence of a policy window means an opportunity to launch an initiative. During the open time, often a short period, policy entrepreneurs must seize the chance by dumping the problems, proposals and political forces into the choice opportunity [12]. Benefiting from policy entrepreneurs' efforts, interests among different parties are balanced and the problem stream, policy stream, and politics stream couple together to achieve policy innovation. In most situations, the three streams are positively coupled, while the negative coupling will miss the policy window with the abortion of the policy-making process [14].

Due to the differences in political systems between China and the US, this paper adapts the MSF by making modifications to its politics stream and applies it to China's domestic policies. As stated above, the politics stream mainly contains national mood, pressure group campaigns and partisan or ideological distribution in Congress. The national mood is the notion that most citizens tend to think along common lines, which can be recognized by policy makers when the mood shifts. Chinese policy makers, at the same level, also intend to promote certain issues catering to the public. Pressure group campaigns, whether supportive or not, can affect the agenda setting. However, the situation has changed and pressure groups seldom launch a campaign in China. The pressure groups work more like interest groups, who may express their opinions during political consultations. Further, the ideological distribution in Congress doesn't comply with China's political system, which is based on multiparty cooperation under the leadership of the Communist Party [15]. Therefore, this paper remains the national mood but replaces the pressure group campaigns and ideological distribution in Congress with the communist \& non-communist parties and the interest groups in the modified framework shown in Figure 1. Notably, the non-communist parties are democratic parties who play the role of democratic supervision in national governance. 


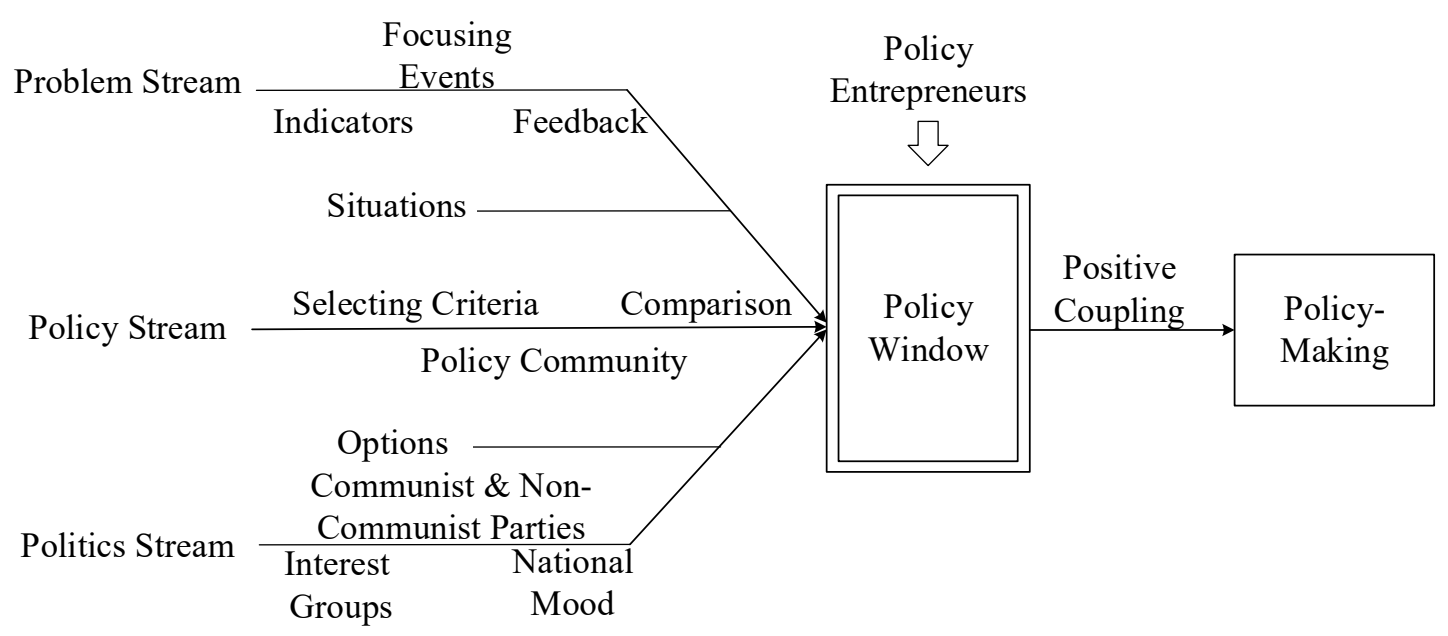

Figure 1. Theoretical framework of the multiple streams. Source: adjusted from [16].

In addition, the application of the MSF should have the openness of the political system as a premise assumption, that is, the degree of public participation in social affairs. Thanks to the improvement of information technology in China, people are getting more aware of what's happening around and showing more enthusiasm for social governance. What's more, the MSF enables policy agenda to be settled under the ambiguity of the problematic preferences, unclear technology and fluid participation in the organization [17]. Therefore, the MSF is generally applicable in explaining China's policy agenda.

\section{MSF Analysis of Intermodal Transport Policy in China}

Three streams of the MSF are discussed in this section, aiming to identify the driving forces of policy setting and test the applicability of the MSF in China's transport policy-making process. More specifically, the problem stream analyzes the intermodal transport volume as indicator, focusing event and feedback from the industry with main concerns being addressed. The policy stream collects and discusses policy suggestions in forming the "policy primeval soup" from experts, practitioners, and relevant government officials, based on their understandings of the problems. The politics stream summarizes the national mood, the appeal of interest groups and the ideologies of communist and non-communist parties, which formulate the political environment for intermodal transport policy in China (see Figure 2 for details).

\subsection{Problem Stream}

The proportion of intermodal transport volume in the total freight transport volume, one of the indicators for evaluating the intermodal transport performance, is relatively low. So far, sea-rail intermodal transport has become the main mode of intermodal transport in China, which is undertaken mainly by coastal ports. Although it has continued to increase in recent years, the volume only accounted for $2 \%$ of the total port throughput, far lower than major ports in Europe $(20-40 \%)[8,18]$. As a result, the lack of economies of scale leads to high transport costs, further hindering the development of the intermodal transport system in China.

The negative growth of pilot lines has become the focusing event that comes along to call attention to the lack of intermodal transport in China. According to the National Intermodal Transport Promotion Conference in 2016, most of the six pilot lines in the PIT project failed to meet the target of a growth rate of more than $20 \%$. Moreover, the intermodal transport volume of some pilot lines showed an average annual growth rate ranging from $-3.8 \%$ to $-2 \%$. One typical example was the port of Tianjin, whose intermodal volume decreased from 125.3 thousand TEU in 2012 to 58.4 thousand TEU in 2015, which only accounted for $0.4 \%$ of the port throughput [19]. 


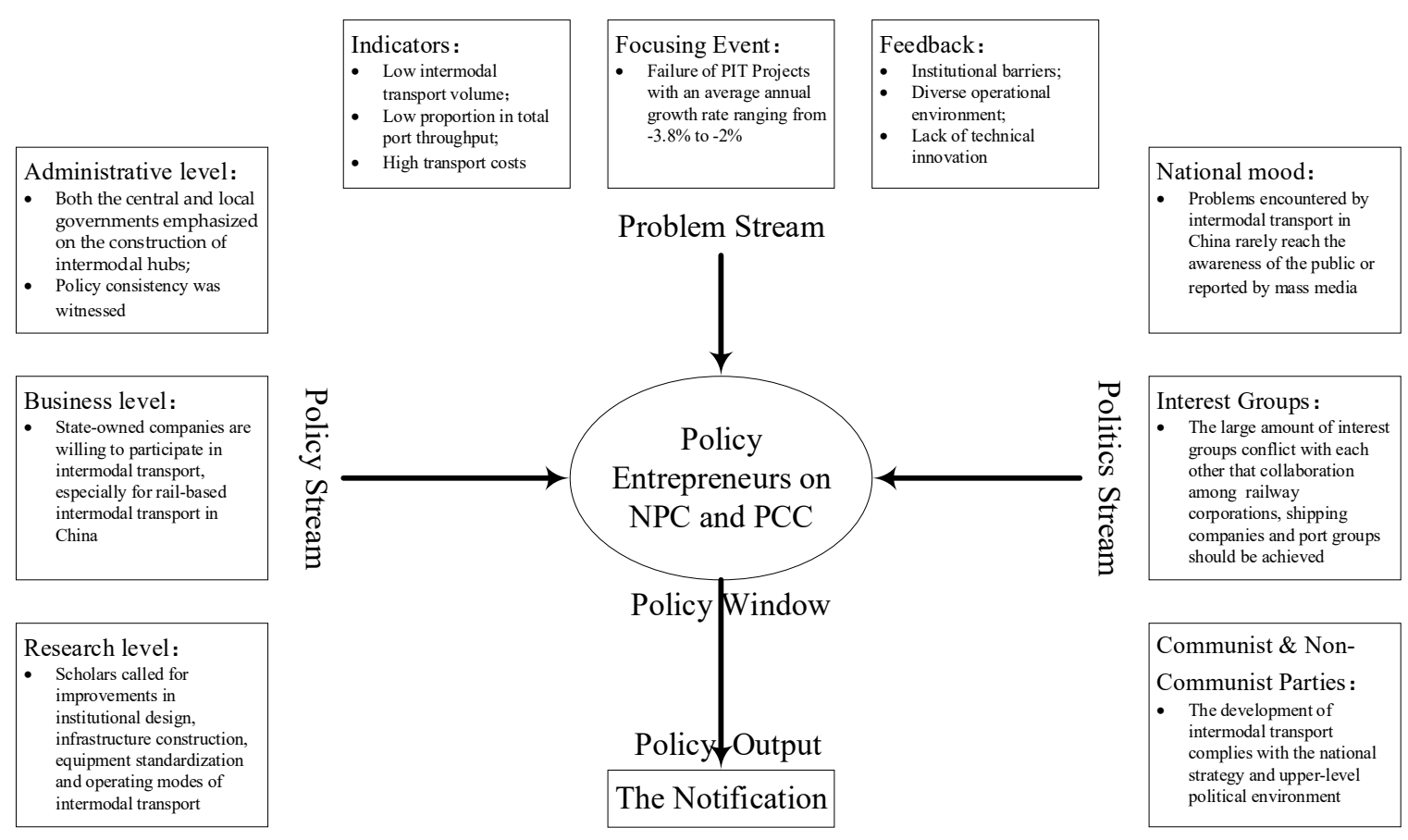

Figure 2. The framework in processing the notification as a national guide on intermodal transport policy. Source: summarized by the authors.

To obtain a better understanding of intermodal transport development in China, in April 2016, the Ministry of Transport conducted a comprehensive investigation to identify factors restricting China's intermodal transport development [20]. As indicated by the received feedback, all factors can be grouped into the following three categories.

The first category is the institutional barriers, including market access, standard unification, and policy disparity. China still lacks unified regulations on the operating qualifications of intermodal transport operators. At present, there are various types of companies that do intermodal transport business, such as port groups, railway corporations, freight forwarders, and third-party logistics providers. There are neither clear market access conditions for different types of companies, nor a clear division of obligation and responsibility, leading to companies' low market participation. In terms of intermodal transport criteria, there are discrepancies with respect to equipment standards, documents, and loading procedures among different modes of transport, resulting in high transshipment costs [21]. In addition, regional policy disparities of intermodal transport development increase competition in the freight market in China.

Second, the diverse operational environment, including operational mechanism and infrastructure construction, hinders the development of intermodal transport in China. The degree of marketization varies among regions with separated operational mechanism. Take the railway sector as an example: the establishment of the China Railway Corporation accelerated the degree of marketization of the railway sector, but it still failed to meet market requirements of operating efficiency [22]. With regard to infrastructure, although the construction of inland container distribution centers receives support from government development planning, there is still inadequate infrastructure and superstructure in the short run [23].

Last but not least, the lack of technical innovation is another significant barrier to intermodal transport development in China. Fortunately, innovative equipment such as piggyback transportation, double-stack containers, and innovative organization models have been tried in some regions to improve transport efficiency. Although some preliminary explorations in loading and unloading equipment, operational processes, and organization models have been obtained, technical innovation still has a lot of room for improvement. 
The above three categories of factors restricting China's intermodal transport development enable both the industry and government departments to better understand the problems of intermodal transport in China from a systematic perspective by considering institutional, operational, and technical barriers.

\subsection{Policy Stream}

When the problems of intermodal transport are identified through indicators, focusing events, and feedback, the attention of experts, practitioners, and relevant government officials will be attracted, aiming to propose corresponding policy recommendations for solving the identified problems. This finally forms the "policy primeval soup" related to intermodal transport. Since the members of the policy community come from all walks of life, they have different values, professionalism, and personal experiences. Therefore, it is necessary to set certain selection criteria for assessing the applicability of the policy recommendations. As shown in Table 1, this paper selects different policy entrepreneurs within the policy community, including government officials, business entrepreneurs, and scholars. As observed, all government officials focus on the "intermodal hub construction", showing the policy consistency between the central (Ministry of Transport) and local governments (Shanghai and Guangdong). Such policy consistency is of vital importance in policy making [24]. All business entrepreneurs seek tactical development in their business fields. Scholars put forward policy suggestions on the development of China's intermodal transport in terms of institutional design [23], infrastructure construction [25], equipment standardization [26], and operating modes [27]. These theoretical breakthroughs converge into an ideological trend, affecting the decisions of government officials and business entrepreneurs.

Table 1. Policy primeval soup of intermodal transport in China.

\begin{tabular}{|c|c|c|c|}
\hline Characteristic & Representative & Policy Recommendations & Remark \\
\hline Government Official & Xiaopeng Li & $\begin{array}{c}\text { Develop port-based intermodal } \\
\text { transport. }\end{array}$ & Minister of Transport \\
\hline Government Official & Qiang Li & $\begin{array}{l}\text { Make up for shortcomings and } \\
\text { construct a modern integrated } \\
\text { transportation system. }\end{array}$ & $\begin{array}{l}\text { Secretary of Shanghai } \\
\text { Municipal Committee }\end{array}$ \\
\hline Government Official & Xi Li & $\begin{array}{l}\text { Construct an integrated } \\
\text { transportation hub for intermodal } \\
\text { transport. }\end{array}$ & $\begin{array}{l}\text { Secretary of Guangdong } \\
\text { Provincial Party } \\
\text { Committee }\end{array}$ \\
\hline Business entrepreneur & Lirong Xu & $\begin{array}{c}\text { Construct intermodal transport } \\
\text { center. }\end{array}$ & $\begin{array}{l}\text { Chairman of COSCO } \\
\text { Shipping Group }\end{array}$ \\
\hline Business entrepreneur & Linghong Li & $\begin{array}{l}\text { Implement pilot lines for sea-rail } \\
\text { intermodal transport. }\end{array}$ & $\begin{array}{c}\text { President of Ningbo Port } \\
\text { Group }\end{array}$ \\
\hline Business entrepreneur & Dongfu Lu & $\begin{array}{c}\text { Promote rail-based intermodal } \\
\text { transport. }\end{array}$ & $\begin{array}{l}\text { General Manager of } \\
\text { China Railway } \\
\text { Corporation }\end{array}$ \\
\hline Scholar & Yijiang Fan [23] & $\begin{array}{l}\text { Build a multi-scale, multi-cargo and } \\
\text { multi-modal transport system in line } \\
\text { with China's national conditions. }\end{array}$ & $\begin{array}{l}\text { Macroeconomic Research } \\
\text { Institute }\end{array}$ \\
\hline Scholar & Zhiwen Li [25] & $\begin{array}{l}\text { Formulate unified norms focusing } \\
\text { on the adjustment of private law } \\
\text { relationships in intermodal } \\
\text { transport. }\end{array}$ & $\begin{array}{l}\text { Dalian Maritime } \\
\text { University }\end{array}$ \\
\hline Scholar & Ning Chen [26] & $\begin{array}{l}\text { Establish an intermodal transport } \\
\text { customs supervision center. }\end{array}$ & $\begin{array}{l}\text { Southwest Jiaotong } \\
\text { University }\end{array}$ \\
\hline
\end{tabular}

Source: Collected from the mass media and CNKI database (www.cnki.net).

Before the Notification, a bunch of policies and regulations were proposed to facilitate the development of intermodal transport in China. However, as indicated by the low growth rate of intermodal transport, none of them was implemented successfully. [28]. In May 2016, a conference on 
promoting intermodal transport in China was held to exchange ideas among enterprises, government departments, research institutions, and other participants involved in the intermodal transport network. Several major policy recommendations were put forward to promote intermodal transport through optimizing access layout and railway entry to ports, enhancing technological innovation and standardization, fostering market participation, improving institutional designs of management systems, laws, regulations, and cooperation mechanisms.

In the policy stream, a series of policy suggestions are summarized based on theoretical discussions and gradually attracting the attention of policy entrepreneurs within the policy community. Their technicality, economics, and operability are tested and gradually unified, aiming to form policy contents with high recognition.

\subsection{Politics Stream}

First, the national mood is an external factor of the policy agenda, which exerts pressure on the policy decision-making process, thereby promoting the generation and formulation of policies [29]. However, as an indispensable sector of the national economy, problems encountered by intermodal transport in China rarely reach the awareness of the public or get reported by mass media. This is because revolution and innovation in the transport industry are always embedded in the change of the whole industry chain, such as China's supply side reform [30].

Second, the appeal of interest groups is also a key factor in the politics stream. The formulation and implementation of policies are the result of the concerted efforts of parties with common interests [31]. When developing intermodal transport in China, not only are government departments involved, but other interest groups, such as railway corporations, shipping companies, port groups, and other relevant enterprises, also participate in intermodal transport. The above interest groups usually directly affect the effectiveness of policy implementation, especially under China's economic system of "keeping public ownership as the mainstay of the economy and allowing diverse forms of ownership to develop side by side" [32]. Therefore, it is necessary to consider collaboration among these interest groups, aiming to push policies forward.

Third, the ideologies of communist and non-communist parties have played a dominant role in the policy-making process in China. As discussed above, the political system in China is under the leadership of the Communist Party of China. Since 2012, the new leader group has taken the "Belt and Road Initiative", "West China Development", "Yangtze River Economic Belt", and other strategies as the new engines of China's economic development. When implementing these strategies, a series of transport policy propositions have been formed. Taking the "Belt and Road Initiative" as an example, improving transport capacity and efficiency has become an important objective of its subprojects. Since then, the upper-level political environment of intermodal transport policy making has matured [33].

\subsection{Coupling of the Three Streams}

The policy window represents the opportunity to enter the formal agenda of policy making under the effort of policy entrepreneurs. At a critical time, a problem is brought up with a solution, which allows the event to finally pass through the policy agenda and be resolved, that is, the positive coupling of the problem, policy, and politics streams. Factors leading to opening the policy window can be a natural event or a political activity [34]. Although most factors are unpredictable, such as the spread of natural disasters and epidemics, the policy window of intermodal transport in China is foreseeable because of routine political activity, that is, the National People's Congress (NPC) and the Political Consultative Conference (PCC) held every year. For instance, the proposals of PCC members, acting as the policy entrepreneurs, will be reviewed, approved, and then enter the agenda of the conference. Such policy proposals will eventually be undertaken by the relevant departments in the state council. If proposals related to intermodal transport are highly valued, the formulation of related policies can be promoted [15]. 
The coupling of the problem stream, policy stream, and politics stream requires the presence of policy entrepreneurs to soften decision-making groups in understanding, accepting, and passing the policy proposals [29]. Under China's political system, the identity of a policy entrepreneur ranges from a farmer, factory worker, scholar, company manager to a government official. However, it is noteworthy that their identities can be changed through their roles in government departments, enterprises, and institutions. A well-known scholar in a specific industry, appointed by the Organization Department, may also be a business entrepreneur of a state-owned enterprise. As a result, the multiplicity of identities has led to the coupling of the three streams dependent not only on the timeline, but also on the forming and evolving process [35]. Meanwhile, multi-identity policy entrepreneurs provide a shortcut to soften and promote the policy agenda thanks to their advantages in professional knowledge and influence in politics [36,37].

In the past few years, several government departments, such as the National Development and Reform Commission, the Ministry of Transport, and the Customs Bureau, have issued a number of regulations and policies to facilitate the development of intermodal transport in China. We collected the documents identifying "intermodal", "multimodal", "comprehensive transportation", etc., as keywords from the official website of the Ministry of Transport. Most of the intermodal transport policies were introduced after 2011. As seen in Table 2, these regulations and policies focus mainly on transport restructuring and reform, the construction of the transport corridor, and standardized systems. However, as of the end of 2016, these regulations and policies were limited to the joint promulgation of a single or fewer than three government departments and did not form a national-level implementation of plans or guidance.

Table 2. Related regulations and policies on intermodal transport in China (2011-2016).

\begin{tabular}{|c|c|c|c|c|}
\hline Title & Background & Date & Issuer & Key Points \\
\hline $\begin{array}{l}\text { Implementation Plan for } \\
\text { Port Intermodal } \\
\text { Transport Construction } \\
\text { in the "13th Five-Year } \\
\text { Plan" of the Yangtze } \\
\text { River Economic Belt }\end{array}$ & $\begin{array}{l}\text { Requirements for } \\
\text { facilitating the port } \\
\text { distribution system } \\
\text { along the Yangtze } \\
\text { river. }\end{array}$ & 07/12/2016 & $\begin{array}{l}\text { National } \\
\text { Development and } \\
\text { Reform } \\
\text { Commission } \\
\text { (NDRC), Ministry } \\
\text { of Transport, China } \\
\text { Railway } \\
\text { Corporation }\end{array}$ & $\begin{array}{l}\text { Foster intermodal } \\
\text { transport operators; } \\
\text { build intermodal } \\
\text { transport } \\
\text { information } \\
\text { platforms. }\end{array}$ \\
\hline $\begin{array}{l}\text { Action Plan for the } \\
\text { Construction of Large } \\
\text { Logistics Channels } \\
(2016-2020)\end{array}$ & $\begin{array}{l}\text { Requirements for } \\
\text { supporting the } \\
\text { long-term planning } \\
\text { of the logistics } \\
\text { industry. }\end{array}$ & 07/12/2016 & NDRC & $\begin{array}{l}\text { Rely on the Northern, } \\
\text { Eastern and Southern } \\
\text { container hub port } \\
\text { groups as intermodal } \\
\text { transport hubs to } \\
\text { improve the } \\
\text { transport system. }\end{array}$ \\
\hline $\begin{array}{l}\text { Development plan of } \\
\text { China Railway Express } \\
(2016-2020)\end{array}$ & $\begin{array}{l}\text { Requirements for } \\
\text { increasing the } \\
\text { transport volume of } \\
\text { China Railway } \\
\text { Express. }\end{array}$ & 19/10/2016 & $\begin{array}{l}\text { China Railway } \\
\text { Corporation }\end{array}$ & $\begin{array}{l}\text { Enhance the service } \\
\text { of China Railway } \\
\text { Express. }\end{array}$ \\
\hline $\begin{array}{l}\text { Suggestions on } \\
\text { Promoting Supply-side } \\
\text { Structural Reforms and } \\
\text { Cost Reduction and } \\
\text { Efficiency Improvement } \\
\text { in the Logistics Industry }\end{array}$ & $\begin{array}{l}\text { Requirements for the } \\
\text { supply-side } \\
\text { structural reform and } \\
\text { logistics costs } \\
\text { reduction. }\end{array}$ & 16/08/2016 & $\begin{array}{l}\text { Ministry of } \\
\text { Transport }\end{array}$ & $\begin{array}{l}\text { Promote the } \\
\text { standardization of } \\
\text { intermodal transport } \\
\text { and advanced } \\
\text { organization of } \\
\text { transport. }\end{array}$ \\
\hline
\end{tabular}


Table 2. Cont.

\begin{tabular}{|c|c|c|c|c|}
\hline Title & Background & Date & Issuer & Key Points \\
\hline $\begin{array}{l}\text { Implementation Plan to } \\
\text { Improve Market } \\
\text { Environment and } \\
\text { Promote the Multimodal } \\
\text { Transport Development }\end{array}$ & $\begin{array}{l}\text { Requirements for the } \\
\text { integration of } \\
\text { transportation and } \\
\text { logistics. }\end{array}$ & $10 / 06 / 2016$ & NDRC & $\begin{array}{l}\text { Strengthen } \\
\text { multimodal } \\
\text { transport services; } \\
\text { expand international } \\
\text { transport; promote } \\
\text { equipment } \\
\text { standardization. }\end{array}$ \\
\hline $\begin{array}{l}\text { Notice on Carrying out } \\
\text { Demonstration Projects } \\
\text { related to Intermodal } \\
\text { Transport }\end{array}$ & $\begin{array}{l}\text { Requirements for } \\
\text { correcting the failure } \\
\text { of PIT projects. }\end{array}$ & $21 / 07 / 2015$ & $\begin{array}{l}\text { Ministry of } \\
\text { Transport }\end{array}$ & $\begin{array}{l}\text { Carry out } \\
\text { demonstration } \\
\text { project of intermodal } \\
\text { transport. }\end{array}$ \\
\hline $\begin{array}{l}\text { Implementation } \\
\text { Opinions on } \\
\text { Accelerating the } \\
\text { Development of Railway } \\
\text { Containers and } \\
\text { Containerized } \\
\text { Transportation }\end{array}$ & $\begin{array}{l}\text { Requirements for } \\
\text { promoting } \\
\text { containerization in } \\
\text { railway } \\
\text { transportation. }\end{array}$ & $26 / 04 / 2015$ & $\begin{array}{l}\text { China Railway } \\
\text { Corporation }\end{array}$ & $\begin{array}{l}\text { Promote the } \\
\text { development of } \\
\text { intermodal transport } \\
\text { in the aspects of } \\
\text { container operation, } \\
\text { service guarantee, } \\
\text { and cooperation } \\
\text { between rail and } \\
\text { water transport. }\end{array}$ \\
\hline $\begin{array}{l}\text { Administrative } \\
\text { Measures for Tax Refund } \\
\text { (Exemption) at the Port } \\
\text { of Departure }\end{array}$ & $\begin{array}{l}\text { Requirements for } \\
\text { supporting the cash } \\
\text { flow management of } \\
\text { international traders. }\end{array}$ & $28 / 08 / 2014$ & $\begin{array}{l}\text { State } \\
\text { Administration of } \\
\text { Taxation }\end{array}$ & $\begin{array}{l}\text { Tax incentives for } \\
\text { intermodal transport. }\end{array}$ \\
\hline $\begin{array}{l}\text { Medium and Long-term } \\
\text { Planning for the } \\
\text { Development of the } \\
\text { Logistics Industry } \\
\text { (2014-2020) }\end{array}$ & $\begin{array}{l}\text { Requirements for } \\
\text { creating a healthy } \\
\text { environment in the } \\
\text { logistics industry. }\end{array}$ & $12 / 09 / 2014$ & State Council & $\begin{array}{l}\text { Promote intermodal } \\
\text { transport for bulk } \\
\text { cargo. }\end{array}$ \\
\hline $\begin{array}{l}\text { Guiding Opinions on } \\
\text { Accelerating the } \\
\text { Development of Sea-Rail } \\
\text { Intermodal Transport }\end{array}$ & $\begin{array}{l}\text { Requirements for } \\
\text { accelerating the PIT } \\
\text { projects. }\end{array}$ & 29/9/2011 & $\begin{array}{l}\text { Ministry of } \\
\text { Transport }\end{array}$ & $\begin{array}{l}\text { Construct network; } \\
\text { strengthen the } \\
\text { establishment of } \\
\text { infrastructure and } \\
\text { standards; foster } \\
\text { market players; } \\
\text { improve information } \\
\text { technology. }\end{array}$ \\
\hline
\end{tabular}

Source: collected from the official website of the Ministry of Transport.

Concerns about intermodal transport peaked in March 2016 during the NPC and PCC. Following the proposal of "Developing Intermodal Transport and Constructing Comprehensive Transportation System" by Yaping Wang, director of the Wuhan Railway Bureau, a total of 13 representatives focused on the construction of the transport system in seven documents and put forward corresponding policy proposals. As shown in Table 3, with the softening of the policy entrepreneurs, the decision makers are paying close attention to intermodal transport. The Ministry of Transport issued the "Notice on Investigating the Development of Intermodal Transport Across the Entire Industry Chain" in April 2016 in order to investigate the status, problems, and policies of intermodal transport in China. In September 2016, the State Council and the Ministry of Transport convened in separate executive meetings, which reviewed and adopted the "Opinions on Promoting the Development of Intermodal Transport" [38]. Finally, in January 2017, 18 departments jointly issued the Notification. At this point, the development of intermodal transport was officially upgraded to a national strategy. Since then, local governments have taken actions to promote the development of intermodal transport; for example, Henan, Shandong, and Jiangsu successively introduced their provincial-level implementation plans. 
Table 3. Comments and suggestions in the National People's Congress (NPC) and the Political Consultative Conference (PCC).

\begin{tabular}{|c|c|c|c|}
\hline Year & Position & Representatives & Comments \\
\hline 2016 & $\begin{array}{l}\text { Director of Wuhan } \\
\text { Railway Bureau }\end{array}$ & Yaping Wang & $\begin{array}{l}\text { Build a comprehensive transport } \\
\text { system to develop intermodal transport. }\end{array}$ \\
\hline 2016 & $\begin{array}{l}\text { Chairman of Southeast Coastal } \\
\text { Railway (Fujian) }\end{array}$ & Naiwu Chen & $\begin{array}{l}\text { Promote coordination among various } \\
\text { transport modes. }\end{array}$ \\
\hline 2016 & $\begin{array}{l}\text { Deputy General Manager of } \\
\text { China Railway Corporation }\end{array}$ & Kaizhou Peng & $\begin{array}{l}\text { Optimize railway freight transport } \\
\text { structure. }\end{array}$ \\
\hline 2016 & Chairman of Wuhan PCC & Chao Wu & $\begin{array}{l}\text { Develop intermodal transport based on } \\
\text { Wuhan Yangtze River New District. }\end{array}$ \\
\hline 2016 & $\begin{array}{l}\text { Chairman of Gansu } \\
\text { Provincial Committee }\end{array}$ & Chongrui Ning & $\begin{array}{l}\text { Develop the Lan-Yu road-rail-water } \\
\text { intermodal transport and open the } \\
\text { logistics channels in the Western } \\
\text { hinterland. }\end{array}$ \\
\hline 2017 & - & $\begin{array}{l}\text { Delegation from } \\
\text { Lianyungang City }\end{array}$ & $\begin{array}{l}\text { Make intermodal bills of lading to } \\
\text { promote the development of China } \\
\text { Railway Express. }\end{array}$ \\
\hline 2017 & $\begin{array}{l}\text { Executive Deputy Director of } \\
\text { Chongqing Liangjiang } \\
\text { New Area }\end{array}$ & Zongwei Tang & $\begin{array}{l}\text { Build an intermodal transport center in } \\
\text { the upper reaches of the Yangtze River. }\end{array}$ \\
\hline 2017 & $\begin{array}{l}\text { Vice Governor of Gansu } \\
\text { Province }\end{array}$ & Hongming Xia & $\begin{array}{l}\text { Construct marshalling center to reduce } \\
\text { the operating cost of China Railway } \\
\text { Express. }\end{array}$ \\
\hline 2017 & - & $\begin{array}{l}\text { Delegation from } \\
\text { Henan Province }\end{array}$ & $\begin{array}{l}\text { Construct international logistics center } \\
\text { for intermodal transport. }\end{array}$ \\
\hline 2018 & $\begin{array}{l}\text { Member of the Central } \\
\text { Committee of China } \\
\text { Democratic League }\end{array}$ & Guanghong Ding & $\begin{array}{l}\text { Use intermodal transport to improve } \\
\text { transportation efficiency. }\end{array}$ \\
\hline 2018 & Director of Chongqing Customs & Weiwei Liu & $\begin{array}{l}\text { Promote intermodal transport on the } \\
\text { Yangtze River. }\end{array}$ \\
\hline 2018 & $\begin{array}{l}\text { Director of Hohhot } \\
\text { Railway Bureau }\end{array}$ & Jiyi Zhang & $\begin{array}{l}\text { Adjust the structure of container } \\
\text { transport and develop green } \\
\text { transportation. }\end{array}$ \\
\hline 2018 & $\begin{array}{l}\text { Vice President of Jinan Academy } \\
\text { of Sciences }\end{array}$ & Liming Ma & $\begin{array}{l}\text { Develop a regional logistics center in } \\
\text { Jinan, Shandong province. }\end{array}$ \\
\hline 2019 & $\begin{array}{l}\text { Chief Engineer of China Railway } \\
\text { Bridge Survey and Design } \\
\text { Institute Group Co., Ltd. }\end{array}$ & Zongyu Gao & $\begin{array}{l}\text { Based on the development of } \\
\text { intermodal transport in the Yangtze } \\
\text { River, carry out research on intermodal } \\
\text { transport technology and formulate } \\
\text { standard specifications for intermodal } \\
\text { transport. }\end{array}$ \\
\hline 2019 & $\begin{array}{l}\text { Vice President of Shanghai } \\
\text { Academy of Sciences }\end{array}$ & Amin Cao & $\begin{array}{l}\text { Build rail lines into port terminals and } \\
\text { improve the construction of intermodal } \\
\text { transport networks in the Yangtze River } \\
\text { Delta region. }\end{array}$ \\
\hline 2019 & - & $\begin{array}{l}\text { Delegation from } \\
\text { Zhejiang Province }\end{array}$ & $\begin{array}{l}\text { Improve information sharing for } \\
\text { intermodal transport, and unify } \\
\text { planning among different transport } \\
\text { modes. }\end{array}$ \\
\hline
\end{tabular}




\section{Key Factors of Policy Making}

Although the promulgation of the Notification has aroused strong responses from the transport industry, it's only a framework that indicates the direction of development. More detailed policies and implementation schemes should be put forward for sustainable policy support. However, no more substantial progress has been made after the promulgation of the Notification. Through the analytic lens of the MSF, we can find some key factors to explain the insufficient development of intermodal transport in China, and then we could speed up the policy agenda by improving the identified factors.

1. Multi-level collaboration: collaboration among multiple interest groups is an essential motivation for pushing forward the policy agenda for intermodal transport in China. In practice, there are still many problems, such as unclear responsibilities, poor connections, and unbalanced benefits among different parties; in particular, the appeals of rail corporations and other interest groups have not been fully considered [39]. Therefore, the balance and coordination among those interest groups have become a key factor in the sustainable formulation and implementation of intermodal transport policy. On the other hand, regulations and policies from multiple departments seem to be more effective than those from a single department. The policy proposals formed by the Ministry of Transport are more likely to encounter implementation obstacles, while the jointly issued ones consider the joint interests of all groups and are more conducive to promoting the development of intermodal transport. To achieve multi-level collaboration, an institutional design of negotiation should be set as a formal agenda in the policy-making process. In this case, it is suggested that the Ministry of Transport should coordinate the other government departments during the proposal of policy documents (e.g., get the customs' support in transport tax refund policy) and should schedule regular meetings with interest groups.

2. Inspiration of national mood: the increasing public enthusiasm for social governance is going to inspire the potential of the national mood in policy making. As an important measurement of the transport industry, logistics costs have a straightforward impact on people's costs of living. However, public awareness of the transport industry is not limited to its influence on the economy. People are more concerned with transport safety and environmental protection. At present, the entire transport system relies heavily on road transport in China. While tens of thousands of trucks cause congestion in the city, they also cause huge hidden dangers to traffic safety, such as exhaust emissions causing a decline in the quality of the urban environment. The development of intermodal transport is adapting to the increasing public awareness and requirements for transport safety and environmental protection, aiming to reduce road traffic and improve urban air quality. As a result, the inspiration of the national mood will accelerate the policy agenda. Although it's a step-by-step process and it may take time to root the concept of green and low-carbon development in people's daily life, the public awareness of transport safety and environmental protection can be aroused by more propaganda from the governmental and non-governmental organizations [40], indicating their important roles in forming the problem stream.

3. Diversification of policy entrepreneurs: policy entrepreneurs with diverse identities come to the stage. Such multiplicity has led to changes in the independence of the problem stream, policy stream, and politics stream. Especially for the policy stream and politics stream, they can converge since a professional scholar or business entrepreneur could also be a deputy in the NPC or PCC. Relying on the roles of the policy entrepreneurs, policy proposals get closer to the decision level. The diversification of policy entrepreneurs can be accelerated through the rotation system among state-owned enterprises, research institutions, government departments, and organizations [41]. In China's institution system, state-owned enterprises provide positions for government officials, which facilitates the policy setting agenda and supports the industrial practice and policy implementation due to the dual roles of the policy entrepreneurs. 


\section{Conclusions}

A sustainable policy environment is of crucial importance in fostering and promoting the intermodal transport system. However, China's intermodal transport policy was intermittent and unsustainable before the proposal of the Notification, hindering the development of intermodal transport. As a guidance, the Notification demonstrates a systematic design of the intermodal transport system and directs the sustainable intermodal transport policy in China. This paper takes the promulgation of the Notification as a typical case to analyze the decision-making process of China's intermodal transport policy, which further proves the applicability of the MSF in China's transport sector. The driving forces embedded in the three streams and the policy-making process of the Notification are discussed as follows: with regard to the problem stream, the low proportion of intermodal transport volume (indicator) and the failure of the pilot lines (focusing event) raised concerns from the industry and caught the attention of policymakers. A comprehensive investigation of the current status of intermodal transport development in China (feedback) indicated a range of constraints at the institutional, environmental, and technical levels. In the policy stream, a series of solutions were then proposed by the policy community, including scholars, practitioners, and government officials under their particular criteria and comparison. With the combined effect of the national mood, interest groups, and the communist \& non-communist parties, the politics stream of intermodal transport policy has gradually matured in China. The presence and softening of the policy entrepreneurs in the NPC and PCC led the solutions to be valued by decision-making groups and enter the formal agenda, eventually forming a national-level policy.

As a result, this paper not only tests the applicability of the modified MSF in formulating China's intermodal transport policy by including China's political characteristics (e.g., the communist \& non-communist parties), but also identifies the key factors of facilitating intermodal transport in China to provide breakthrough points for sustainable policy making in the future. Another implication of this paper is to recognize the roles of multi-level collaboration in balancing the interests among parties pursuing policy innovation [13,42], national mood in accelerating the policy agenda, and the diversified identities of policy entrepreneurs in coupling the policy and politics streams, which advances the existing findings [43,44]. By improving the identified factors and roles, government officials and policy entrepreneurs could promote the promulgation of related intermodal transport policies.

However, some limitations still exist in this paper. For example, key factors remain to be strengthened for a sustainable intermodal transport policy system. The Notification provides policy directions, but specific implementation plans have not yet been clarified. The policy agenda for intermodal transport in China can be expedited with collaboration among multiple interest groups, inspiration of national mood, and diversification of policy entrepreneurs' identities. These limitations point out new directions for future research.

Author Contributions: Both J.G. and W.S. contributed equally to this manuscript. This work was created under the supervision of X.W. All authors have read and agree to the published version of the manuscript.

Funding: This research was funded by China Scholarship Council (201908310090) and the Innovative Talent Program for Graduate Students of Shanghai Maritime University (2019YBR003).

Conflicts of Interest: The authors declare no conflict of interest.

\section{References}

1. Hanaoka, S.; Regmi, M.B. Promoting intermodal freight transport through the development of dry ports in Asia: An environmental perspective. Iatss Res. 2011, 35, 16-23. [CrossRef]

2. López-Navarro, M.Á. Environmental factors and intermodal freight transportation: Analysis of the decision bases in the case of Spanish motorways of the Sea. Sustainability 2014, 6, 1544-1566. [CrossRef]

3. Agamez-Arias, A.D.M.; Moyano-Fuentes, J. Intermodal transport in freight distribution: A literature review. Transp. Rev. 2017, 37, 782-807. [CrossRef] 
4. Zhao, X.; Tang, Q. Analysis and strategy of the Chinese logistics cost reduction. Int. J. Bus. Manag. 2009, 4, 188-191. [CrossRef]

5. Accounting for about $15 \%$ of GDP, Twice of the United States (US), How Can China's Logistics Cost Be Reduced? Sina News. 18 January 2017. Available online: http://finance.sina.com.cn/roll/2017-01-18/docifxzutkf1945407.shtml (accessed on 14 April 2020).

6. Horn, B.E.; Nemoto, T. Intermodal Logistics Policies in the EU, the US and Japan. Transp. Policy Stud. Rev. 2005, 7, 2-14.

7. Emission Reduction Should Be Strengthened from the Transportation Sector. China Economic Net. 21 January 2019. Available online: http://paper.ce.cn/jjrb/html/2019-01/21/content_382229.htm (accessed on 14 April 2020).

8. International Union of Railways. 2018 Report on Combined Transport in Europe; UIC: Pairs, France, 2019; Available online: https://uic.org/IMG/pdf/2018_report_on_combined_transport_in_europe.pdf (accessed on 3 March 2020).

9. Weng, X.; Du, X. Restudy on macro logistics cost of China. Mod. Econ. 2015, 6, 1173-1179. [CrossRef]

10. $\mathrm{Mu}, \mathrm{R}$. Coupling of Problems, Political Attention, Policies and Institutional Conditions: Explaining the Performance of Environmental Targets in the National Five-Year Plans in China. Sustainability 2018, 10, 1477. [CrossRef]

11. Notification on Further Encouraging Intermodal Transport. In Ministry of Transport; 4 January 2018. Available online: http://www.mot.gov.cn/2018wangshangzhibo/gxbshncl/xiangguanziliao/201802/t20180207_2988774. html (accessed on 3 March 2020).

12. Cohen, M.D.; March, J.G.; Olsen, J.P. A garbage can model of organizational choice. Adm. Sci. Q. 1972, 17, 1-25. [CrossRef]

13. Jones, M.D.; Peterson, H.L.; Pierce, J.J.; Herweg, N.; Bernal, A.; Lamberta Raney, H.; Zahariadis, N. A river runs through it: A multiple streams meta-review. Policy Stud. J. 2016, 44, 13-36. [CrossRef]

14. Blum, S. The multiple-streams framework and knowledge utilization: Argumentative couplings of problem, policy, and politics issues. Eur. Policy Anal. 2018, 4, 94-117. [CrossRef]

15. Zhu, X.; Sun, B. Tianjin Binhai new area: A case study of multi-level streams model of Chinese decision-making. J. Chin. Political Sci. 2009, 14, 191-211. [CrossRef]

16. Zahariadis, N. Ambiguity and Choice in Public Policy: Political Manipulation in Democratic Societies; Georgetown University Press: Washington, DC, USA, 2003.

17. Herweg, N.; Zahariadis, N.; Zohlnhöfer, R. The multiple streams framework: Foundations, refinements, and empirical applications. In Theories of the Policy Process; Routledge: London, UK, 2018; pp. 17-53.

18. Sun, L.; XU, P.; Liang, X.J. Countermeasures about Development of Sea-rail Transport in China. China Port 2011, 4, 24-27.

19. Ding, L.; Qin, F. Heading Forward of China's Port Container Sea-water Intermodal Transport. China Port 2016, 7, 1-3.

20. Notice on Investigating the Development of Intermodal Transport Across the Entire Industry Chain. In Ministry of Transport; 26 April 2016. Available online: http://xxgk.mot.gov.cn/jigou/ysfws/201604/t20160426_ 2978658.html (accessed on 5 March 2020).

21. Zang, Z.H.; Shi, Y. The Problems and Suggestions on Sea-water Intermodal Transport in China. Water Transp. Manag. 2018, 40,1-4.

22. Gao, Y.; Li, W.D.; You, X.Y. Research on the efficiency evaluation of China's railway transport enterprises with Network DEA. China Soft Sci. 2011, 5, 176-182.

23. Fang, Y.J.; Xie, Y.R.; Wang, M. The Path and Mission of Intermodal Transport System Construction in China. Micro Econ. Res. 2017, 7, 158-165.

24. Wan, Z.; Chen, J.; Sperling, D. Institutional barriers to the development of a comprehensive ballast-water management scheme in China: Perspective from a multi-stream policy model. Mar. Policy 2018, 91, 142-149. [CrossRef]

25. Li, Z.W.; Lu, Q. The Configuration of Intermodal Transport Law in China Under BRI. Law Sci. Mag. 2016, 37, 57-64.

26. Chen, N.; Wang, X.L.; Zhang, L. Research on the Business Mode of Intermodal Transport Customs Supervision Center. Logist. Technol. 2016, 35, 39-42. 
27. Shen, B.; Shen, Z.G.; Zhang, J.L. The Configuration of the "One Bills of Lading" Mode for Intermodal Transport. Railw. Transp. Econ. 2018, 40, 20-23.

28. China's Intermodal Transport Volume Accounts for Less than $3 \%$ of Total Freight Volume. Xinhua News. 10 September 2018. Available online: http://www.xinhuanet.com//2018-09/10/c_1123407498.htm (accessed on 5 March 2020).

29. Kingdon, J.W. Agendas, Alternatives, and Public Policies, 2nd ed.; HarperCollins College Publishers: New York, NY, USA, 1995.

30. Zhang, Y.; Nie, R.; Shi, R.; Zhang, M. Measuring the capacity utilization of the coal sector and its decoupling with economic growth in China's supply-side reform. Res. Conserv. Recycl. 2018, 129, 314-325. [CrossRef]

31. Kaya, C. The impact of interest group diversity on legal implementation in the European Union. J. Eur. Public Policy 2018, 25, 567-585. [CrossRef]

32. Zhang, Y. On the organic combination of public ownership and market economy. China Political Econ. 2018, 1, 67-83. [CrossRef]

33. Xie, S.X.; Sun, X.M. Logistic Intermodal Transport Mode and Strategic Research under BRI. Railw. Purch. Logist. 2017, 1, 51-54.

34. Shafritz, J.M.; Layne, K.S.; Borick, C.P. Classics of Public Policy, 1st ed.; Pearson Longman: London, UK, 2005.

35. Fang, H.; Yang, J. Policy Agenda Analysis Based on Multiple Streams Model-Case Study of the Shared Bicycle. E-Government 2019, 1, 86-93.

36. Wang, G.H.; Zhu, D.Q. The Factors Influencing the formation of the Rural Revitalization Strategy and its Coupling Logic-A Perspective from the Multiple Streams Theory. J. Manag. 2018, 31, 1-9.

37. Huang, J.H.; Xu, Z.Q. Analysis of the Policy Agenda of the <Ordinance on School Bus Safety (Draft)>A Perspective from the Multiple Streams Model. J. Public Manag. 2012, 9, $19-31$.

38. Leveraging the Efficiency of Intermodal Transport to Promote the Upgrading of Transport System. In Ministry of Transport; 9 September 2016. Available online: http://www.mot.gov.cn/buzhangwangye/lixiaopeng/ zhongyaohuodonghejianghua/201609/t20160909_2085159.html (accessed on 21 March 2020).

39. Xu, Q.; He, T.J.; Mao, B.H. Current Situation and Develepment of Sea-water Intermodal Transport in China. J. Transp. Syst. Eng. Inf. 2018, 18, 194-200.

40. Agarwal, A. Role of NGOs in the Protection of Environment. J. Environ. Res. Dev. 2008, 2, 933-938.

41. Brødsgaard, K.E. Politics and business group formation in China: The Party in control? China Q. 2012, 211, 624-648. [CrossRef]

42. Capano, G. Understanding policy change as an epistemological and theoretical problem. J. Comp. Policy Anal. 2009, 11, 7-31. [CrossRef]

43. Knaggård, Å. The multiple streams framework and the problem broker. Eur. J. Political Res. 2015, 54, 450-465. [CrossRef]

44. Hammond, D.R. Policy Entrepreneurship in China's Response to Urban Poverty. Policy Stud. J. 2013, 41, 119-146. [CrossRef]

(C) 2020 by the authors. Licensee MDPI, Basel, Switzerland. This article is an open access article distributed under the terms and conditions of the Creative Commons Attribution (CC BY) license (http://creativecommons.org/licenses/by/4.0/). 